\title{
THE AFFORDANCES OF IMPROVISED RESOURCES IN PHYSICAL SCIENCES CLASSROOMS
}

\author{
Koketso Ntladi, \& Sam Ramaila \\ Department of Science and Technology Education, University of Johannesburg (South Africa)
}

\begin{abstract}
The development of meaningful conceptual understanding in science teaching and learning is a key ingredient required for the development of scientifically literate citizenry. The use of improvised resources to demystify the complexity of scientific phenomena is of crucial significance. In recognition of this crucial imperative, the study explored the pedagogical affordances associated with the use of improvised resources in Physical Sciences classrooms at a selected South African township school. The study adopted a case study design located within the interpretive research paradigm. Data was collected through semi-structured interviews and lesson observations involving three purposively selected Physical Sciences teachers. The study demonstrated that the use of improvised resources promotes active learner participation, sustained intellectual engagement in the teaching and learning activity, enhancement of teachers' pedagogical content knowledge, development of learners' reflective and cognitive skills as well as the provision of meaningful opportunities for collaborative learning and development of meaningful conceptual understanding. Key findings of the study have profound implications for pedagogic innovation within the broader South African educational context.
\end{abstract}

Keywords: Improvisation, low-cost resources, pedagogic innovation.

\section{Introduction}

The significance of pedagogic innovation as a means to enhance meaningful science teaching and learning cannot be over-emphasized. A substantial number of schools in South Africa are still under-resourced and this predicament adversely affects the provision of quality education for all. The use of improvised instructional resources can be adopted as part of pedagogic innovation to demystify abstract scientific concepts. Teacher professional development interventions ought to provide sustainable opportunities for teachers to enhance their expertise on the integration of improvised instructional resources in science teaching and learning. There is a critical need to grapple with the complex disjuncture between theoretical teaching and practical teaching with a view to meaningfully implement contemporary pedagogic approaches such as inquiry-based learning. Ong'amo, Ondigi and Omariba (2017) posit that students frequently taught using improvised resources performed better than those rarely taught using improvised resources. Yet, teachers lack appropriate skills to use improvised teaching resources in schools (Akuma \& Callaghan, 2016). This study primarily explored the pedagogical affordances of improvised resources in physical sciences classrooms in South African township schools.

\section{Research design and methodology}

The study adopted a case study design located within the interpretive research paradigm. Data was collected through semi-structured interviews and lesson observations involving three purposively selected Physical Sciences teachers in South African township schools. These township schools were largely under-resourced.

\section{Findings}

Table 1 below provides teachers' views on the pedagogical affordances of improvised resources in physical science classrooms. While the teachers expressed fundamental appreciation of the pedagogical affordances of improvised resources in physical sciences teaching and learning, they further outlined challenges associated with the integration of improvised resources in their lessons. The prevalence of these challenges may be attributed to lack of appropriate professional training on the integration of improvised resources in physical sciences teaching and learning. 
Table 1. Teachers' views on the affordances of improvised resources in physical sciences classrooms.

\begin{tabular}{|c|c|c|c|c|c|c|c|}
\hline & \multicolumn{7}{|c|}{ Key areas of investigation } \\
\hline Teachers & $\begin{array}{l}\text { Improvised } \\
\text { resources and } \\
\text { the challenges }\end{array}$ & $\begin{array}{l}\text { Using } \\
\text { improvised } \\
\text { resources in } \\
\text { classroom }\end{array}$ & $\begin{array}{l}\text { How to } \\
\text { develop } \\
\text { lessons } \\
\text { based on } \\
\text { improvised } \\
\text { resources }\end{array}$ & $\begin{array}{l}\text { Can improvised } \\
\text { resources } \\
\text { improve } \\
\text { pedagogical } \\
\text { content } \\
\text { Knowledge? }\end{array}$ & \begin{tabular}{|l} 
How can \\
improvised \\
resources \\
stimulate \\
learner \\
engagement?
\end{tabular} & $\begin{array}{l}\text { How can } \\
\text { improvised } \\
\text { resources be } \\
\text { used to enhance } \\
\text { learner } \\
\text { conceptual } \\
\text { understanding? }\end{array}$ & 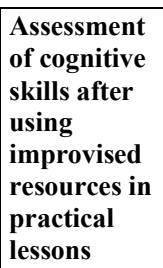 \\
\hline \begin{tabular}{|l|} 
Teacher 1 \\
\end{tabular} & $\begin{array}{l}\text { Challenge is } \\
\text { cost-free } \\
\text { teaching } \\
\text { resources may } \\
\text { not } \\
\text { be user- } \\
\text { friendly }\end{array}$ & $\begin{array}{l}\text { By doing } \\
\text { experiments } \\
\text { with improvised } \\
\text { resources }\end{array}$ & \begin{tabular}{|l|} 
By \\
diversifying \\
improvised \\
resources
\end{tabular} & $\begin{array}{l}\text { Yes as } \\
\text { improvised } \\
\text { resources } \\
\text { broaden } \\
\text { content of } \\
\text { subject }\end{array}$ & $\begin{array}{l}\text { Interest of } \\
\text { learners is } \\
\text { stimulated }\end{array}$ & \begin{tabular}{|l|} 
Learners can \\
relate to \\
importance of \\
resources used
\end{tabular} & $\begin{array}{l}\text { Summative } \\
\text { assessment }\end{array}$ \\
\hline \begin{tabular}{|l|} 
Teacher 2 \\
\end{tabular} & $\begin{array}{l}\text { They don't } \\
\text { resemble real } \\
\text { life scenario }\end{array}$ & $\begin{array}{l}\text { Make models to } \\
\text { resemble } \\
\text { real life } \\
\text { scenario and } \\
\text { demonstrations }\end{array}$ & $\begin{array}{l}\text { Outcomes } \\
\text { must match } \\
\text { models } \\
\text { Align } \\
\text { objectives } \\
\text { with lesson } \\
\text { plan }\end{array}$ & $\begin{array}{l}\text { Yes, can help } \\
\text { interpret } \\
\text { situations and } \\
\text { improve } \\
\text { communication }\end{array}$ & $\begin{array}{l}\text { By discussions } \\
\text { Visuals } \\
\text { participation }\end{array}$ & $\begin{array}{l}\text { Different } \\
\text { interpretations of } \\
\text { each } \\
\text { situation }\end{array}$ & $\begin{array}{l}\text { Group } \\
\text { Work }\end{array}$ \\
\hline
\end{tabular}

\subsection{Examples of improvised resources designed by the teachers}

The teachers demonstrated remarkable creativity in relation to the design of improvised resources used in physical sciences teaching and learning. Examples of improvised resources designed to demonstrate filtration as a key experimental mechanism are illustrated in Figure 1 below.

Figure 1. Improvised resources designed to demonstrate filtration.
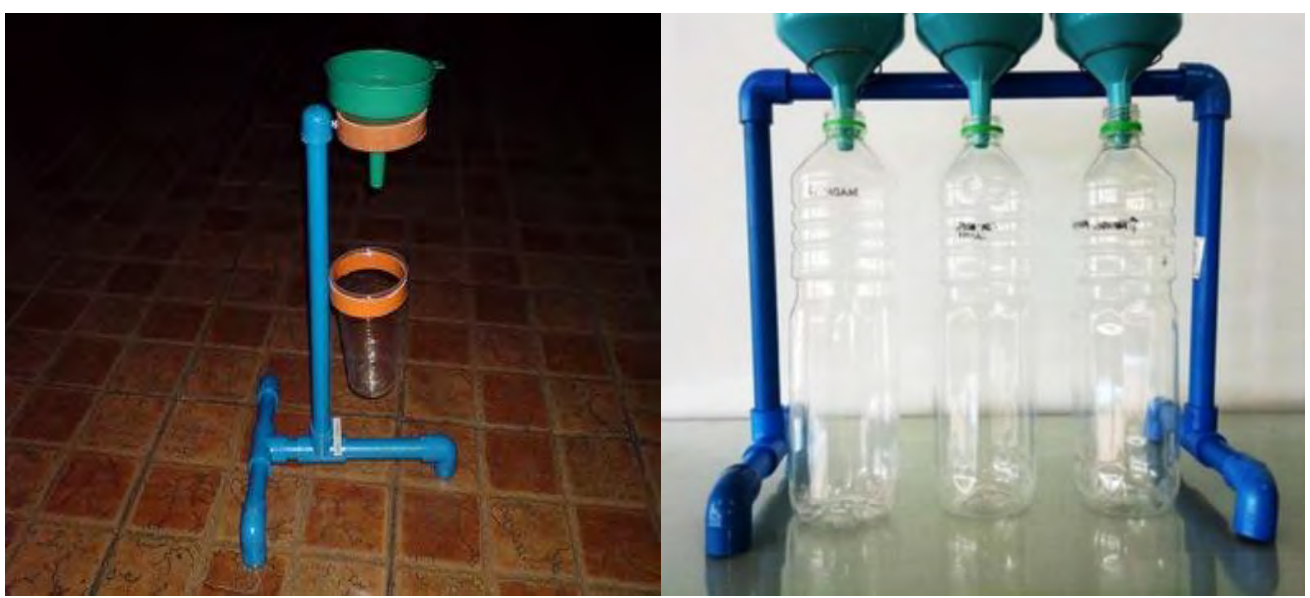
Electric motors play an increasingly important role in everyday life. Figure 2 below depicts improvised resources that were designed to explain the operation of a direct current motor.

Figure 2. Improvised resources designed to explain the operation of a direct current motor.

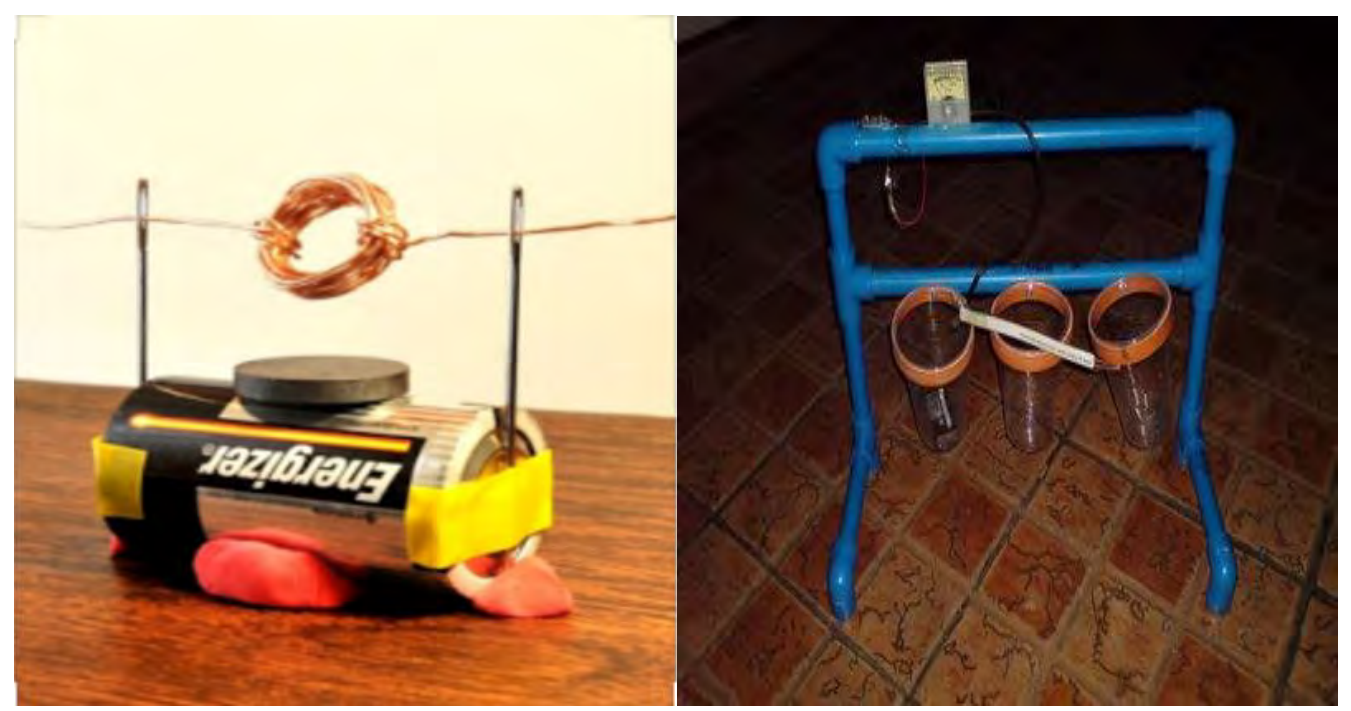

The development of learners' understanding of electromagnetic phenomena can be a daunting task for teachers. An improvised resource designed to explain the mapping of a magnetic field is illustrated in Figure 3 below.

Figure 3. Improvised resource designed to explain the mapping of a magnetic field.

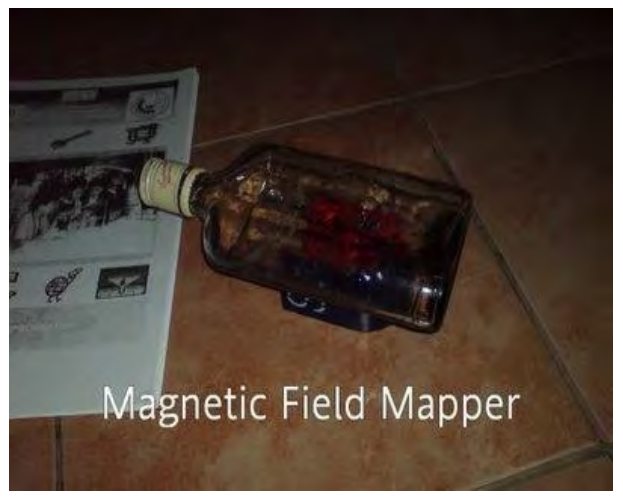

Electrolysis is a fundamental chemical phenomena that ought to be fully understood by learners in physical sciences classrooms. An improvised resource designed to demystify the complexity of electrolysis is depicted in Figure 4 below.

Figure 4. Improvised resource designed to demystify the complexity of electrolysis.

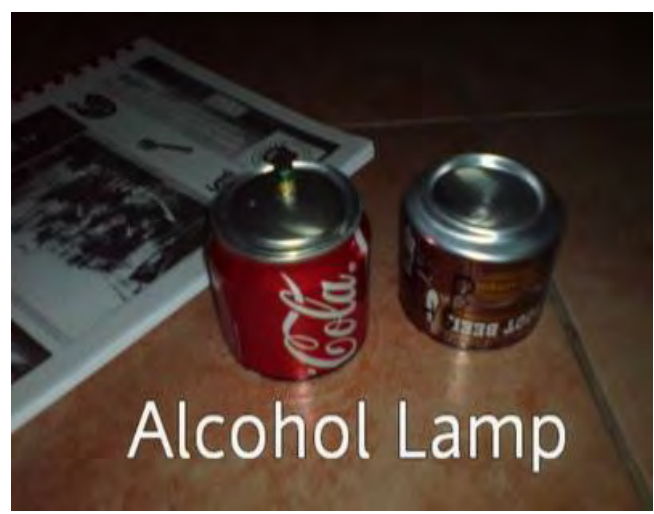




\section{Discussion}

The study demonstrated that the use of improvised resources promotes active learner participation, sustained intellectual engagement in the teaching and learning activity, enhancement of teachers' pedagogical content knowledge, development of learners' reflective and cognitive skills as well as the provision of meaningful opportunities for collaborative learning and development of meaningful conceptual understanding. The teachers expressed fundamental appreciation of the pedagogical affordances of improvised resources in physical sciences teaching and learning. However, they outlined challenges associated with the integration of improvised resources in their lessons. The prevalence of these challenges may be attributed to lack of appropriate professional training on the integration of improvised resources in physical sciences teaching and learning. Behrendt and Franklin (2014) posit that improvised resources enhance science learning and development of meaningful conceptual understanding. In addition, improvised resources help teachers deliver information more accurately especially in instances where repetitions are required for concrete learning to occur (Ong'amo, Ondigi \& Omariba, 2017). However, many science teachers are not equipped with skills to incorporate new ideas in the teaching of science in the classroom (Silverstein, Dubner, Glied \& Loike, 2009). Harnessing the pedagogical affordances of improvised resources requires the provision of sustainable teacher development opportunities on the integration of improvised resources in science lessons. The key advantage of using improvised resources is that they can be produced from readily available materials within the environment (Asare, Parker \& Osei-Himah, 2018). According to Asare, Parker and Osei-Himah (2018), the whole purpose of using improvised teaching resources is to achieve the same desired outcomes that could be achieved with the traditional laboratory resources. The key goal is essentially to get learners actively engaged in science teaching and learning in order to acquire necessary scientific skills through involvement in hands-on learning activities. Improvised resources are often produced to address learning difficulties (Akuma \& Callaghan, 2016). The use of improvised resources has profound implications for the enhancement of the overall quality of science education and human capital development within the broader South African context.

\section{Conclusion}

The use of improvised instructional resources appears to promote active learner participation, sustained intellectual engagement in the teaching and learning activity, enhancement of teachers' pedagogical content knowledge, development of learners' reflective and cognitive skills as well as the provision of meaningful opportunities for collaborative learning and development of meaningful conceptual understanding. There is a critical need to harness the pedagogical affordances of improvised resources to foster pedagogic innovation that is responsive to the critical needs of learners.

\section{References}

Akuma, F.V. \& Callaghan, R. (2016). Framework for reducing teaching challenges relating to improvisation of science education equipment and materials in schools. Eurasia Journal of Mathematics, Science and Technology Education, 12(10), 2697-2717.

Asare, I., Parker, J. \& Osei-Himah, V. (2018). Teachers' attitude towards improvisation, its effects on the study of science at the Junior high schools in Aowin Municipality- Ghana. International Journal of Education, Learning and Development, 6(4), 90-95.

Behrendt, M. \& Franklin, T. (2014). A review of research on school field trips and their value in education. International Journal of Environmental and Science Education, 9 (3), 235-245.

Ong'amo, B.L., Ondigi, S.R. \& Omariba, A. (2017). Extent of use of Biology instructional resources and effect on students' academic performance in Secondary Schools in Siaya County- Kenya. International Journal for Innovation Education and Research, 5(7), 118-141.

Silverstein, S. C., Dubner, J., Glied, S., \& Loike, J. D. (2009). Teachers' participation in research programs improves their students' achievement in science. Science, 326(5951), 440-442. 